\title{
MHC Class II Gene
}

National Cancer Institute

\section{Source}

National Cancer Institute. MHC Class II Gene. NCI Thesaurus. Code C16616.

A family of genes expressed mainly by antigen presenting cells that encode major histocompatibility complex proteins and are involved in the presentation of fragments from phagocytized extracellular proteins to cytotoxic lymphocytes. 